\title{
Perennial monocropping of khat decreased soil carbon and nitrogen relative to multistrata agroforestry and natural forest in southeastern Ethiopia
}

\author{
Mesele Negash $^{1}\left[\right.$ D Janne Kaseva ${ }^{2} \cdot$ Helena Kahiluoto $^{3}$
}

Received: 19 June 2021 / Accepted: 20 February 2022 / Published online: 7 March 2022

(c) The Author(s) 2022

\begin{abstract}
Monocropping of perennial cash crops providing livelihood for smallholders is replacing native forest throughout the tropics, but there is no direct empirical evidence on the impact on soil organic carbon (SOC) and nitrogen (N) relative to multistrataagroforestry-based cash cropping. In particular, the impact of the conversion of forests and multistrata-agroforestry-based cash cropping to a rapidly expanding perennial monocropping of khat (Catha edulis Forskal) is not known. We investigated the potential of cash cropping integrated in multistrata agroforestry to alleviate SOC and N loss from converted native forest, relative to cash monocropping. We assessed empirically SOC and $\mathrm{N}$ stocks in the 40 -cm-deep soil surface layer of three matched adjacent plots of native forest, multistrata agroforestry, and perennial cash monocropping, within nine replicate groups of the three land uses. The fixed mass method was applied. The estimated rates of the annual SOC and N losses were 3.0 and 3.4 times greater, respectively, in areas converted to khat monocropping than in agroforestry systems producing both coffee (Coffea arabica) and khat. Additionally, the carbon and $\mathrm{N}$ contents in leaf litter and fine roots were greater in agroforestry than in khat. The results indicated that multistrata-agroforestry-based cash cropping maintains most of the SOC and N stocks of converted native forests lost in conversion to cash monocropping khat than in agroforestry-based cash cropping. This warrants economic incentives to prevent the loss of the current stocks, while enabling cash crop income by smallholders. Reducing forest SOC and N stock decline in agroforestry through system management deserves attention as well.
\end{abstract}

Keywords Agroforestry · Catha edulis (khat) · East Africa $\cdot$ Monocropping $\cdot$ Native forest $\cdot$ Soil carbon $\cdot$ Soil nitrogen

\section{Introduction}

Soil represents the largest terrestrial carbon (C) pool and can preserve captured $\mathrm{C}$ longer than aboveground biomass (Lehmann 2006). Sufficient stocks of $C$ and nitrogen (N) are also a precondition to soil productivity (Lal et al. 2015). Rapid tropical deforestation (Sloan and Sayer 2015) currently accounts for 12 to $15 \%$ of the annual global C

Communicated by Luis Lassaletta

Mesele Negash

meselenegash72@gmail.com

1 Wondo Genet College of Forestry and Natural Resources, Hawassa University, P.O. Box 128, Shashemene, Ethiopia

2 Natural Resources Institute Finland (Luke), Tietotie 4, 31600 Jokioinen, Finland

3 LUT University, Sustainability Science, P.O. Box 20, 53851 Lappeenranta, Finland emissions (Kotowska et al. 2015) and a fourth of the global losses of soil C (Smith et al. 2016). Forests cover 11 to 16\% of the Ethiopian land area, $92 \%$ of which represents native forests (Keenan et al. 2015). The native forests suffer from rapid deforestation (MEFCC 2018), with cash crop plantations being a key driver (Dessie and Kinlund 2008; Mellisse et al. 2018).

To meet the requirements of the Paris Agreement, Ethiopia has a target to reduce the annual net $\mathrm{C}$ emissions by $64 \%$ before 2030 through $\mathrm{C}$ sequestration, half of which through reforestation, sustainable forest management, and agroforestry (MEFCC 2016). Agroforestry integrates trees, including $\mathrm{N}$-fixing legume trees, into the production of food, feed, energy, and cash crops such as coffee (Coffea arabica L) and khat (Catha edulis Forsk.). Export-driven perennial cash monocropping, for example, of cacao (Emich, 2003), tea (Solomon et al. 2002), banana (Powers 2004), oil palm, rubber (de Blécourt et al. 2013; Kotowska et al. 2015; Málaga et al. 2020), and khat (Mekuria 2018; Dessie and Kinlund 
2008; Mellisse et al., 2018), is expanding at the expense of native forest and agroforestry reducing $\mathrm{C}$ and $\mathrm{N}$ stocks in Southeast Asia, Latin America, and East Africa.

The evergreen perennial shrub, khat, is cultivated for its fresh leaves for use as a stimulant in East Africa, southwestern Arabia, and Madagascar (Lemessa 2001). In Ethiopia, cash cropping of also khat has been traditionally integrated within agroforestry systems but is increasingly conducted by monocropping. Coffee still largely integrated into agroforestry systems supports the livelihoods of 15 million farmers and generates $25 \%$ of Ethiopian export earnings (Moat et al. 2017). In recent decades, a high market demand and price have rapidly expanded khat to fields of millions of smallholders (Mellisse et al., 2018; Woldu et al. 2015) making khat to a second-most exported item after coffee. Khat is mainly exported to Somalia, Somaliland, and Djibouti (Tolcha 2020). In parts of Eastern Ethiopia, khat produces up to $70 \%$ of the household income (Feyisa and Aune 2003; Mekuria 2018) having replaced $63 \%$ of the former cultivation area of coffee (Woldu et al. 2015). Khat monocropping is replacing forest and coffee farms also in Eastern, South Central, and South Western Ethiopia (Lemessa 2001; Dessie and Kinlund 2008; Dube et al. 2014; Woldu et al. 2015). This development may create a serious threat to SOC and $\mathrm{N}$ stocks.

SOC and $\mathrm{N}$ stocks are determined by the quality and quantity of the $\mathrm{C}$ and $\mathrm{N}$ flows (Negash and Kanninen 2015) and by the soil biological, chemical, and physical properties (Hombegowda et al. 2016), all of which are affected by the composition and density of the vegetation, the characteristics of climate and topography, and the management and harvest. Impacts on the "microbial pump" control the balance between the priming and entombing effects on stable SOC (Liang and Balser 2012; Liang et al. 2017). Litter is the pathway to $\mathrm{C}$ and $\mathrm{N}$ from plant to soil (Köhler et al. 2008). Litter production and quality vary with stand characteristics, climate and soil, season, and management and harvesting practices (Liu et al. 2004; Dawoe et al. 2010; Murovhi et al. 2012).

The severe consequences of deforestation and perennial cash monocropping to SOC and $\mathrm{N}$ stocks of converted forest and agroforestry are well-known (e.g., Kim et al., 2016; Kassa et al. 2017). However, there is no direct empirical evidence of the impact of native forest conversion to multistrata-agroforestry-based cash cropping relative to perennial monocropping of cash crops such as khat on soil $\mathrm{C}$ and $\mathrm{N}$ stocks. The lack of empirical understanding undermines the potential to combine export income with soil productivity, climate change mitigation, and benefits from potential C payments (Pan et al. 2011; Kahiluoto et al. 2014; Walden et al., 2020). Therefore, this study aimed to empirically quantify the difference between the impact of native forest conversion to multistrata agroforestry and to monocropped khat on the SOC and N stocks in Ethiopian highlands. The hypothesis was that multistrata agroforestry sustains nativeforest-originating SOC and N stocks better than the monocropping of perennial cash crops such as khat.

\section{Materials and methods}

\section{Study sites}

The study was conducted at the Arosa and Abo sites in the Sidama National Region $\left(7^{\circ} 00^{\prime}-7^{\circ} 06^{\prime} \mathrm{N}\right.$ and $38^{\circ} 34^{\prime}-38^{\circ} 37^{\prime}$ E) of Ethiopia (Fig. 1a) because at both sites, there appears a larger native forest patch as well as agroforestry and khat plots immediately next to those forest patches (Fig. 1b). The two study sites are located at altitudes between 1800 and 2300 m.a.s.l. and $18 \mathrm{~km}$ apart from each other. Characterized by a moist to subhumid warm subtropical climate (Abebe 2013), the sites are among the most productive agricultural areas of Ethiopia. The monthly mean temperature is $18-20^{\circ} \mathrm{C}$, and the annual rainfall amount is $1300-1500 \mathrm{~mm}$. The deep, reddish-brown, clayey soils dominated by Nitisols have a relatively high organic matter content and a crumbly and/or subangular blocky structure and are therefore well drained and fertile (FAO 2001).

Historically, the native forest was dominated by indigenous tree species such as Cordia africana Lam., Afrocurps falcatus (Podocarpus falcatus) (Thunb.) R. Br. ex Mirb, Millettia ferruginea (Hochst.) Baker, and Ficus spp. The native sacred forest patches cover 2.1 ha in Arosa and $32.5 \mathrm{ha}$ in Abo; these are remnants of forests representing dry evergreen Afromontane forest that once dominated the entire sites but have been partly replaced by agroforestry and khat monocropping through conversion of native forest. The remaining native forest patches are carefully stewarded by the communities, remaining untouched since the early 1990s. No utilization and management activities are allowed in the native forest patches, while cultivation, weeding, and pruning are carried out in agroforestry sites and khat monocropping.

The dominant agroforestry systems replacing part of the native forest at the sites represent multistrata agroforestry evolved through the selective removal of trees from original forests. Multistrata agroforestry refers to a cropping system where trees, shrubs, and crops such as coffee, khat, and food crops are grown as integrated layers in the same area. In agroforestry systems, native trees, such as Cordia africana Lam, Erythrina brucei Schweinf. Millettia ferruginea (Hochst.) Baker, Olea africana, Croton macrostachyus Del., Afrocarpus falcatus (Podocarpus falcatus) (Thunb.) R. Br. ex Mirb, Vernonia amygdalina Del., and Prunus africana Hook. F, were the dominant tree species until the late 1980s, where after exogenous tree species have 
(a)

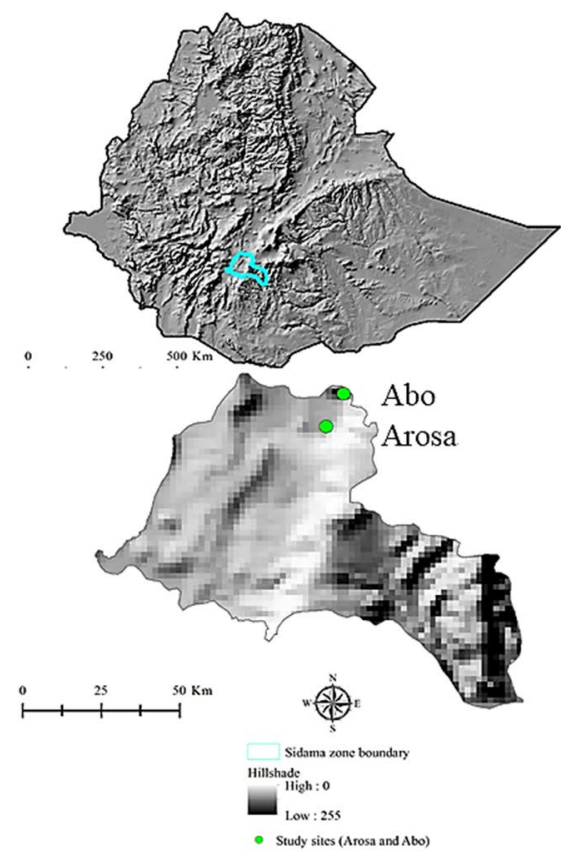

(b)

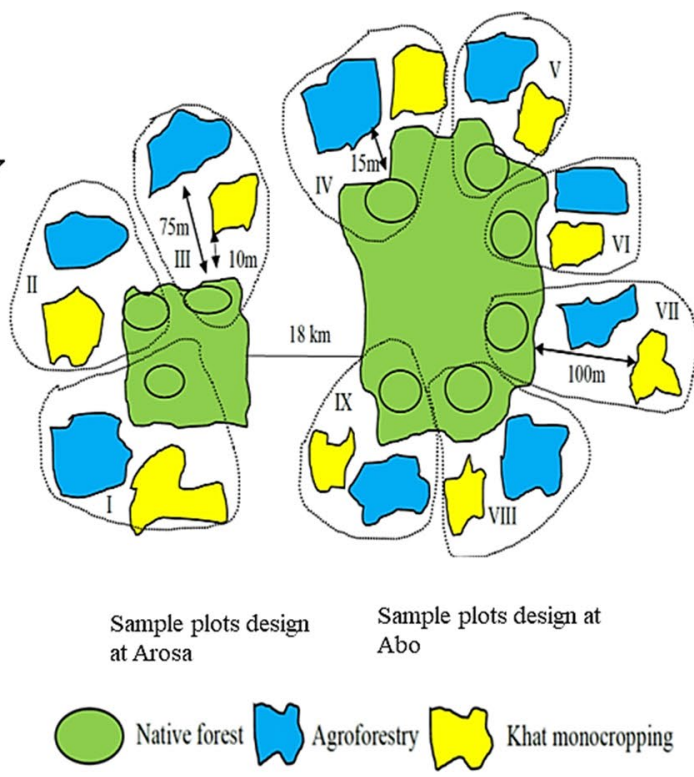

(c)

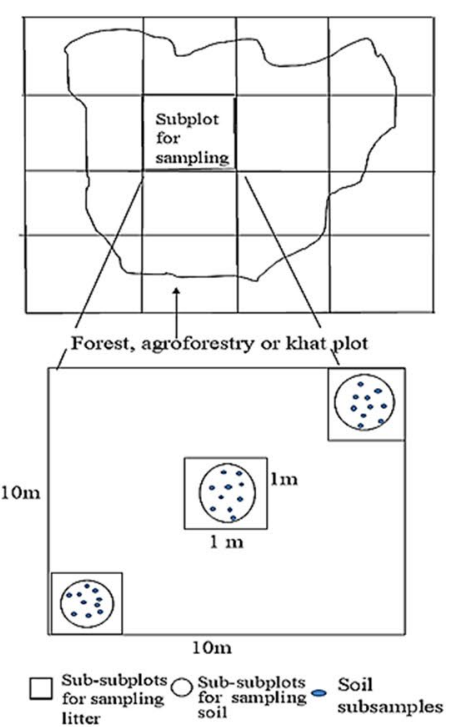

Fig. 1 Spatial design of the sample plots. Location of the study region and sites (a), layout of native forest (two sites located $18 \mathrm{~km}$ apart), and the adjacent agroforestry (AF) and khat monocropping plots (KF), each located 10 to $100 \mathrm{~m}$ from the compared native for-

also been introduced to the system. Perennial food crops such as enset (Ensete ventricosum (Welw.) Cheesman) and perennial cash crops such as coffee and khat are integral parts of the agroforestry system. To a limited extent, annual crops such as wheat (Triticum spp. L.), barley (Hordeum vulgare L.), fava bean (Vicia faba L.), and kale (Brassica oleracea) are integrated in agroforestry. Livestock used to be an integral component of the farming system but is currently rarely included due to a lack of free grazing land and fodder; however, green manure such as enset leaves and household wastes are sources of organic fertilizers and used for mulching. Both khat and coffee serve as the major income sources in the region. The vertical structure of the agroforestry system in the regions commonly consists of an upper layer with canopy tree spp., amid layer with enset, a lower layer with coffee, and a ground layer with herbaceous crops and weeds. Trees in the system provide shade for coffee, fodder, fuel, timber, and construction materials. The farmers also pollard and thin trees.

Native forest was converted both to agroforestry and to khat as well as via agroforestry to khat. With the expansion of khat beginning in the early 1990s, the number of trees in crop fields gradually decreased, and even if khat is cultivated in agroforestry systems together with coffee, an increasing number of khat fields currently lack trees. The khat monocrops are intensively cultivated and thoroughly weeded. est plot within each of the nine genuine replicates with the three land uses (b), and sub-plot design within each forest, $\mathrm{AF}$ and $\mathrm{KF}$ plot, as well as sub-subplot design for sampling litter and soil within each subplot (c)

Fertilizers have not been applied, but pesticides have been used in khat monocropping. Khat is propagated by cutting and can be planted year round. The plant reaches heights of over $30 \mathrm{~m}$; however, in cultivation, it is usually pruned to less than $3 \mathrm{~m}$ (Kim et al 2016). Khat leaves are harvested individually by hand within 2 to 3 years after planting (Dessie and Kinlund 2008). Khat growers harvest foliage biomass 2-3 times per year and sell the products in nearby markets.

The identification of the management history was based on farmer interviews. The duration of agroforestry management of the sampled agroforestry plots varied from 32 to 54 years, and the khat cultivation history on the khat plots varied from 15 to 27 years. The annual rates of SOC and $\mathrm{N}$ stock declines were estimated by dividing the stocks by duration (Rimhanen et al. 2016).

\section{Sampling design}

\section{Sample plots layout}

The assessment was carried out by comparing matched adjacent plots of native forest, multistrata agroforestry, and khat monocropped areas, and these groups of the three adjacent land uses were replicated nine times (Fig. 1b). Three and six groups of the three adjacent plots, each plot representing one of the three land uses, were located at each of the two sites 
of Arosa and Abo, respectively. Consequently, there were 27 plots of the three land uses, each with three sub-subplots for sampling (Fig. 1c) and thus 81 sub-subplots altogether. The distance among the matched adjacent plots of the three compared land uses within each of the nine replicates ranged between 10 and $100 \mathrm{~m}$, and their similarity was primarily secured by the proximity (adjacent plots of the compared three land uses) but verified for elevation, slope, soil type, texture (Table 1), and management history for each plot of each land-use type. The soil of the study area was slightly acidic to neutral, with mean $\mathrm{pH}$ values being equal for the adjacent plots with each land use. Native forest plots had a slightly higher proportion of clay fraction than the adjacent plots of agroforestry and khat monocropping (Table 1), probably due to differences in erosion.

For each of the 27 plots, one subplot of $10 \mathrm{~m} \times 10 \mathrm{~m}$ for sampling was selected (Fig. 1c). To select the sampling subplot location, the forest, agroforestry, and khat plots were visually divided into equal grid points. Each subplot for sampling was randomly selected using a lottery system by assigning a random number to each grid point (Fig. 1c). Within each subplot, three sub-subplots for sampling were randomly established at the center and the corners (Balaguer-Puig et al., 2018). From each sub-subplot, $1 \mathrm{~L}$ sample and one composite soil sample for each of the two depths comprising ten subsamples were collected (Fig. 1c).

\section{Soil sampling}

A wooden sample frame of $1 \mathrm{~m} \times 1 \mathrm{~m}$ composed of square grids of 10 by 10 units $(10 \mathrm{~cm} \times 10 \mathrm{~cm}$ each $)$ was overlaid on the selected sampling points of the farm floor (Fig. 1c). Within a square grid, ten subsamples per sub-subplot and depth $(0-20 \mathrm{~cm}$ and $20-40 \mathrm{~cm})$ were randomly collected with an auger (3.8 $\mathrm{cm}$ diameter), and a composite sample was formed for SOC and $\mathrm{N}$ analyses. The same number of soil samples for bulk density analysis was separately collected using a core sampler with a volume of $442 \mathrm{~cm}^{3}$ from each sampling point and both soil depths. We confined soil sampling to a depth of 0 to $40 \mathrm{~cm}$ because approximately $75 \%$ of the roots are concentrated at the top depth $(0-40 \mathrm{~cm})$, and management practices mainly influence depths of 0 to $30 \mathrm{~cm}$ (O'Rourke et al. 2015). Furthermore, Raizada et al. (2013) observed that nearly $80 \%$ of fine roots were confined to a depth of $0-20 \mathrm{~cm}$ in five fruit tree and three forest tree species. In systems of perennial crops and shade trees, all fine roots, which provide $\mathrm{C}$ and $\mathrm{N}$ inputs to soil, concentrate in the topsoil (Muñoz and Beer 2001).

\section{Litter collection and sampling}

Leaf litter and fine root samples were collected in March immediately after a period of high litterfall from woody species (Negash and Starr 2013). Nested sub-subplots for soil sampling were also used for litter and fine root collection. Litter samples were harvested from three $1 \mathrm{~m} \times 1 \mathrm{~m}$ subsubplots located randomly within each of the $10 \mathrm{~m} \times 10 \mathrm{~m}$ subplots. The samples from each of the three sub-subplots were combined for each subplot. The fresh weight was measured on the site. Litter was sun-dried for 1 day; a 100-g subsample was taken to the laboratory and oven-dried $\left(70{ }^{\circ} \mathrm{C}\right)$ for $24 \mathrm{~h}$ and weighed to determine the dry-to-fresh weight ratio and estimate the dry biomass litter on a hectare basis.

\section{Fine root sampling}

The fine roots $(<2 \mathrm{~mm})$ were extracted from the soil samples for the two depths $(0-20 \mathrm{~cm}$ and $20-40 \mathrm{~cm})$ with a soil core sampler (diameter $7 \mathrm{~cm}$ ). Each soil sample was soaked for $30 \mathrm{~min}$ to facilitate the breakdown of soil aggregates. The samples were washed on a 2-mm sieve overlaid with 1-mm and 0.5-mm sieves (Nygren et al. 2013). The fine roots left on the sieve were extracted by hand. The extracted fine roots were oven-dried at $70{ }^{\circ} \mathrm{C}$ for $24 \mathrm{~h}$ until a constant weight was maintained. The dry biomass of fine roots was calculated using the area of the soil score sampler per depth.
Table 1 Soil physicochemical characteristics of the three land-use types in the Sidama National Region, southern Ethiopia. The values in parentheses are the lower and upper limits of the $95 \%$ confidence intervals of the mean estimates. Comparisons denoted with the different letter $(\mathrm{a}, \mathrm{b}$, or $\mathrm{c})$ differed statistically significantly from each other $(p<0.05)$

\begin{tabular}{lllll}
\hline Soil variable & Unit & Native forest & Agroforestry system & Khat monocropping \\
\hline Altitude & $\mathrm{m}$ & $2116^{\mathrm{a}}(2103,2129)$ & $2051^{\mathrm{a}}(2041,2061)$ & $2051^{\mathrm{a}}(2040,2062)$ \\
Slope & $\%$ & $10-35$ & $10-30$ & $10-30$ \\
$\mathrm{pH}$ & $1: 2.5 \mathrm{H}_{2} \mathrm{O}$ & $6.14^{\mathrm{a}}(6.02,6.26)$ & $6.43^{\mathrm{a}}(6.31,6.55)$ & $6.03^{\mathrm{a}}(5.82,6.24)$ \\
Sand & $\%$ & $12.0^{\mathrm{b}}(11.42,12.58)$ & $26.5^{\mathrm{a}}(26.00,27.00)$ & $23.0^{\mathrm{a}}(21.00,25.00)$ \\
Silt & $\%$ & $29.5^{\mathrm{a}}(27.73,31.27)$ & $24.5^{\mathrm{a}}(22.73,26.27)$ & $29.5^{\mathrm{a}}(27.73,31.27)$ \\
Clay & $\%$ & $58.5^{\mathrm{a}}(57.24,59.76)$ & $49.0^{\mathrm{b}}(46.62,51.38)$ & $47.5^{\mathrm{b}}(47.00,48.00)$ \\
Soil type & & Nitisols & Nitisols & Nitisols \\
\hline
\end{tabular}




\section{Carbon and nitrogen contents of leaf litter and fine roots}

The $\mathrm{C}$ and $\mathrm{N}$ contents in the leaf litter and fine roots were assessed using values from studies representing similar systems and conditions in the Sidama region of Ethiopia as at the sites of this study, supported by other literature. For native forest, we adapted the $\mathrm{C}$ contents of litter and fine roots suggested by the IPCC (2006) and the N contents suggested by Aerts (1997). For the C contents in agroforestry and khat monocropping, we used the values determined by Negash and Starr (2015) and Getnet (2016), respectively; for the N contents, the values found by Negash and Starr (2013) and Assefa et al. (2017) were employed, all representing conditions similar to those in our study sites, supported by the values of Gordon and Jackson (2000) regarding all three land uses. Consequently, the C contents in leaf litter dry matter of $37 \%$ for native forest, $29 \%$ for agroforestry, and 33\% for khat monocropping were used. Regarding fine roots, the C contents in dry matter were $47 \%$ for native forest and khat monocropping and $43 \%$ for agroforestry. Regarding leaf litter, the $\mathrm{N}$ contents in dry matter were $1.4 \%$ for native forest, $2.6 \%$ for agroforestry, and $1.4 \%$ for khat monocropping. A fine root $\mathrm{N}$ content in dry matter of $1.14 \%$ was used across the land-use types.

\section{Soil analyses}

The soil samples for SOC and $\mathrm{N}$ analyses were air-dried and ground $(<2 \mathrm{~mm})$. Total $\mathrm{C}$ and $\mathrm{N}$ concentrations were analyzed by dry combustion at $1250{ }^{\circ} \mathrm{C}$ with a LECO TruMac CN analyzer (Leco Corporation, St. Joseph, MI, USA) using 500-mg soil samples. Analysis was carried out for the original samples and for those treated with $\mathrm{HCl}$ to remove carbonate $\mathrm{C}(0-0.48 \%$, median $0.17 \%)$. The $\mathrm{C}$ contained in the carbonates was determined indirectly by digesting $6-\mathrm{g}$ soil samples with $10 \mathrm{ml}$ of $6 \mathrm{M}$ $\mathrm{HCl}$ for 30 min (Ellert and Rock 2007). Dried soil samples $\left(60{ }^{\circ} \mathrm{C}, 24 \mathrm{~h}\right)$ were analyzed for total $\mathrm{C}$, and the difference between the untreated soil and the $\mathrm{HCl}$-treated soil was taken as the measure of carbonate $\mathrm{C}$. The SOC content was determined as the difference between the total $\mathrm{C}$ content of the untreated soil and the carbonate $\mathrm{C}$ content of the $\mathrm{HCl}-$ treated soil. Bulk density samples were oven-dried at $105{ }^{\circ} \mathrm{C}$ for $24 \mathrm{~h}$ and weighed, and the weights of the $>2 \mathrm{~mm}$ and $<2 \mathrm{~mm}$ fractions were recorded. Bulk density $\left(\rho_{\mathrm{b}}\right)\left(\mathrm{g} \mathrm{cm}^{-3}\right)$ was calculated as the oven-dried weight of the soil divided by the volume of the intact soil core. Soil $\mathrm{pH}$ was measured in deionized water (1:2.5 soil:water) (ES ISO 10390), and soil texture was measured with a hydrometer method (Bouyoucos 1962).

The SOC and total N stocks for each soil depth and the three land-use types were calculated using the fixed mass method (Ellert and Bettany 1995). The method expresses the stocks as the product of the excess soil mass with its $\mathrm{C}$ or $\mathrm{N}$ concentrations of a soil layer relative to the reference soil mass, subtracted from the SOC or N stocks calculated at a fixed depth (Ellert and Bettany 1995). The lowest soil mass to the specified soil depth from all sampling sites $(1540 \mathrm{Mg}$ for $0-20,1670 \mathrm{Mg}$ for $20-40 \mathrm{~cm}$ ) served as the reference soil mass. Such an adjustment is justified because the fixed depth approach systematically overestimates the SOC stocks in land uses with greater bulk densities relative to the land uses with lower bulk densities (Wendt and Hauser 2013).

\section{Statistical analyses}

Due to the skewed distributions of the SOC and N stocks, generalized linear mixed models with a lognormal (with an identity link) and a gamma distribution (with a log link) were used in the analysis. A Gaussian distribution was used for $\mathrm{C} / \mathrm{N}$. The models were fitted using the residual maximum likelihood (REML) or residual pseudolikelihood (REPL) estimation method, with land use (native forest, agroforestry, and khat), depth $(0-20 \mathrm{~cm}, 20-40 \mathrm{~cm})$, and their interaction as fixed effects. Land use was the only fixed effect in the analysis where the depths were combined. The three matched adjacent plots of native forest, agroforestry, and khat were used as a block (replicate). There were nine blocks, and the sites and the blocks within a given site were assumed to be independent and normally distributed random effects. This assumption was made because of the proximity of the sites that were included only to provide a sufficient number of blocks (combinations of the three land uses) and variation among blocks. The variation between the two "sites" was mainly estimated to be zero, which led to its exclusion from the models based on the Kenward-Roger degrees of freedom method (Kenward and Roger 2009).

To improve the accuracy of the measurements, each of the 27 plots consisted of one subplot and three sub-subplots (Fig. 1c). However, the sub-subplots were not used as replicates; the correlation of sub-subplot values was taken into account in the model to avoid pseudoreplication. In these models, the correlation between the measurements of each replicate at the two depths was accounted for by using a heterogeneous or a homogenous compound symmetry covariance structure (Gbur et al. 2012).

The rates of annual SOC and $\mathrm{N}$ losses $(0-40 \mathrm{~cm})$ due to the conversion to khat were calculated based on the number of years since conversion. Because information was lacking on whether the conversion to khat had occurred directly from native forest or via agroforestry, the annual rates of SOC and N stock losses were calculated based on both assumptions. The same statistical models were used as mentioned above, with the following exceptions. The current land uses were agroforestry, khat, and khat via agroforestry. A Gaussian distribution was used in both models, but the variances were estimated separately for each land use because the assumption of equal 
Table 2 Results of the statistical analysis for the fixed effects of bulk density (BD) $\left(\mathrm{g} \mathrm{cm}^{-3}\right)$ and for the soil organic carbon (SOC) and nitrogen $(\mathrm{N})$ concentrations $(\%)$. Degrees of freedom were calculated using the Kenward-Roger method

\begin{tabular}{llll}
\hline $\begin{array}{l}\text { Response vari- } \\
\text { able }\end{array}$ & Effect & F-test $_{\mathrm{df}}$ & $p$-value \\
\hline BD & Land use & $\mathrm{F}_{2,16}=2.82$ & 0.090 \\
& Depth & $\mathrm{F}_{1,24}=67.30$ & $<0.001$ \\
& Land use $\times$ depth & $\mathrm{F}_{2,24}=0.82$ & 0.454 \\
SOC & Land use & $\mathrm{F}_{2,24}=24.12$ & $<0.001$ \\
& Depth & $\mathrm{F}_{1,24}=325.22$ & $<0.001$ \\
& Land use $\times$ depth & $\mathrm{F}_{2,24}=25.75$ & $<0.001$ \\
$\mathrm{~N}$ & Land use & $\mathrm{F}_{2,24}=24.22$ & $<0.001$ \\
& Depth & $\mathrm{F}_{1,24}=342.44$ & $<0.001$ \\
& Land use $\times$ depth & $\mathrm{F}_{2,24}=14.63$ & $<0.001$ \\
\hline
\end{tabular}

variances of three land uses was not met. The suitability of all models was studied by residual analysis. The residuals were checked for normality using a boxplot and plotted against the fitted values, which indicated that the assumptions of the models were adequate. The Westfall method was used for the pairwise comparisons of means (Westfall 1997). A significance level of $\alpha=0.05$ was used in all the analyses if not otherwise stated. Pearson correlation coefficients were calculated for $\mathrm{C} / \mathrm{N}$. Since $\mathrm{C} / \mathrm{N}$ may vary considerably at short distances, all 81 sub-subplot observations were included in the calculation of correlation. The analyses were performed using the GLIMMIX and CORR procedures of the SAS Enterprise Guide 7.1 (SAS Institute Inc., Cary, NC, USA).

\section{Results}

\section{Bulk density and soil organic carbon and nitrogen concentrations}

The bulk density was not statistically significantly different among the land-use types but differed between the soil depths (Table 2). The median estimate of the bulk density at $0-20 \mathrm{~cm}$ was slightly higher for khat than for native forests and agroforestry plots (Table 3 ).

The SOC and N concentrations showed statistically significant differences among the land-use types, and the differences depended on soil depth (Table 2). The native forest surface soil layer had 1.8 and 1.7 times the SOC and N concentrations of the agroforestry surface soil layer and 2.2 and 2.3 times the SOC and $\mathrm{N}$ concentrations of the khat surface soil layer $(p<0.001)$, respectively (Table 3 ). No evident difference existed in the concentrations of SOC and N in the deeper $(20-40 \mathrm{~cm})$ soil layer between the native forest and agroforestry systems $(p>0.05)$; however, both were higher than the concentrations of SOC and N in the same deeper soil layer of the khat plots (for SOC, $p=0.016$ and 0.053 , and for $\mathrm{N}, p=0.001$ and 0.011 , in the native forest and agroforestry plots, respectively, relative to khat monocropping).

\section{Soil organic carbon stock}

The SOC stock declines following the conversion of native forest to agroforestry systems were concentrated in the surface soil, whereas in khat monocropping, the declines were found in the deeper soil layer as well (Fig. 2a). The SOC stock in the agroforestry plots was $57 \%$ of that in the native forest for the soil depth of $0-20 \mathrm{~cm}(p<0.001)$, whereas no evident difference existed at the soil depth of $20-40 \mathrm{~cm}$ $(p=0.608)$. In the case of khat, the difference from forest was more uniform across the soil profile, i.e., $54 \%$ for $0-20 \mathrm{~cm}(p<0.001)$ and $26 \%$ for $20-40 \mathrm{~cm}(p=0.021)$. The contributions of the deeper soil layer $(20-40 \mathrm{~cm})$ to the total SOC stock were greater in the agroforestry plots and khat monocropping, with values of $43 \%$ and $42 \%$, respectively, of the total stock, than for native forest (31\%).

The overall SOC stock estimates for agroforestry at depths of $0-40 \mathrm{~cm}$ were $68 \%$ of those in the native forest $(p=0.001)$, with a difference of $65.2 \mathrm{Mg} \mathrm{ha}^{-1}$ (Fig. 2c). Correspondingly, in khat monocropping, the SOC stock was $55 \%$ of that in the native forest, and the absolute difference in
Table 3 Test results for the comparisons of median bulk density (BD) $\left(\mathrm{g} \mathrm{cm}^{-3}\right)$, soil organic carbon (SOC) concentrations $(\%)$, and nitrogen $(\mathrm{N})$ concentrations $(\%)$ for two soil depths within the land uses. Generalized linear mixed models with lognormal (SOC and N) and gamma (BD) distributions were used in the analysis due to the skewed distributions. Comparisons denoted with the different letter ( $\mathrm{a}, \mathrm{b}, \mathrm{c}$, or d) differed statistically significantly from each other $(p<0.05)$. However, land uses were compared only within depths and depths within land use. The values in parentheses are the lower and upper limits of the $95 \%$ confidence intervals of the mean estimates

\begin{tabular}{lllll}
\hline Response variable & Depth $(\mathrm{cm})$ & Native forest & Agroforestry & Khat \\
\hline BD & $0-20$ & $1.04^{\mathrm{a}}(0.94,1.14)$ & $1.01^{\mathrm{a}}(0.92,1.12)$ & $1.15^{\mathrm{a}}(1.04,1.27)$ \\
& $20-40$ & $1.20^{\mathrm{b}}(1.09,1.33)$ & $1.19^{\mathrm{b}}(1.08,1.31)$ & $1.28^{\mathrm{b}}(1.16,1.42)$ \\
SOC & $0-20$ & $6.92^{\mathrm{a}}(6.07,7.89)$ & $3.95^{\mathrm{b}}(3.47,4.51)$ & $3.13^{\mathrm{c}}(2.75,3.57)$ \\
& $20-40$ & $2.70^{\mathrm{c}}(2.37,3.08)$ & $2.52^{\mathrm{cd}}(2.21,2.88)$ & $2.05^{\mathrm{d}}(1.80,2.34)$ \\
N & $0-20$ & $0.60^{\mathrm{a}}(0.52,0.69)$ & $0.36^{\mathrm{b}}(0.31,0.41)$ & $0.26^{\mathrm{c}}(0.23,0.30)$ \\
& $20-40$ & $0.24^{\mathrm{c}}(0.21,0.28)$ & $0.21^{\mathrm{c}}(0.18,0.24)$ & $0.16^{\mathrm{d}}(0.14,0.18)$ \\
\hline
\end{tabular}



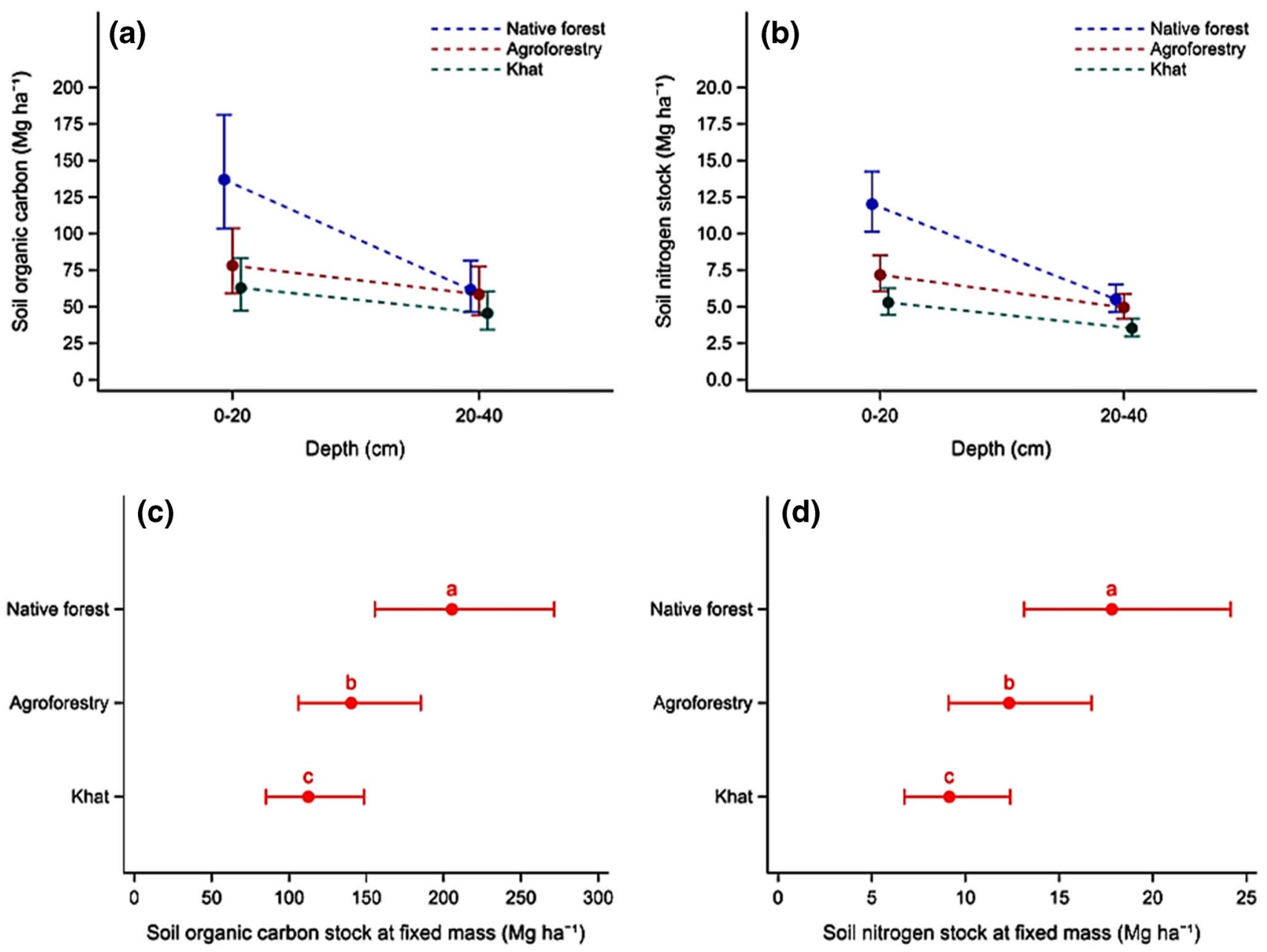

Fig. 2 Soil carbon and nitrogen stocks according to land use and soil depth. Mean estimates of soil organic carbon (SOC) (a) and median estimates of nitrogen (N) (b) stocks depending on the soil depth and SOC (c) and N stocks (d) at the soil depth of $0-40 \mathrm{~cm}$ by the fixed

mass method. The lines show the lower and upper limits of the $95 \%$ confidence intervals for the means (SOC) and medians (N), and different letters on the lines indicate statistically significant differences $(p<0.05)$. The sample sizes were $162(\mathbf{a}, \mathbf{b})$ and $81(\mathbf{c}, \mathbf{d})$

the SOC stock was $93.1 \mathrm{Mg} \mathrm{ha}^{-1}(p<0.001)$. The SOC stock in khat monocropping was $20 \%$ lower than that observed in agroforestry $(p=0.025)$.

\section{Nitrogen stock}

The $\mathrm{N}$ stock at the soil depth of $0-20 \mathrm{~cm}$ was $7.1 \mathrm{Mg} \mathrm{ha}^{-1}$ in the agroforestry plots and $5.2 \mathrm{Mg} \mathrm{ha}^{-1}$ in the khat monocropping. The $\mathrm{N}$ stock in the $0-40 \mathrm{~cm}$ soil layer depth in the agroforestry plots represented $60 \%$ and $44 \%$ of that in native forest, respectively (Fig. 2b). The N stock in the $20-40 \mathrm{~cm}$ subsurface soil layer of forest was different from that in the khat monocropping $(p=0.002)$, but a difference could not be shown relative to the agroforestry plots $(p=0.371)$ (Fig. 2b). The $\mathrm{N}$ stock in the agroforestry plots at a depth of $0-40 \mathrm{~cm}$ was $12.3 \mathrm{Mg} \mathrm{ha}^{-1}$, and that in the khat monocropping plots was $9.1 \mathrm{Mg} \mathrm{ha}^{-1}$. Consequently, the $\mathrm{N}$ stock in agroforestry

plots was $69 \%(p=0.005)$, and that in khat monocropping was $51 \%(p<0.001)$ of that in forest (Fig. 2d).

\section{Rates of soil organic carbon and nitrogen stock losses}

The mean annual rate of decline of SOC after the conversion of native forest was estimated at $1.52 \mathrm{Mg} \mathrm{ha}^{-1}$ and $4.89 \mathrm{Mg} \mathrm{ha}^{-1}$ for agroforestry and khat, respectively. This result implies that the rate of decline of the SOC stock due to deforestation under khat was three times under agroforestry (Fig. 3a). The rate of annual $\mathrm{N}$ loss due to agroforestry and khat monocropping had a mean value of $0.13 \mathrm{Mg} \mathrm{ha}^{-1}$ and $0.46 \mathrm{Mg} \mathrm{ha}^{-1}$, respectively, showing that deforestation for khat decreased the $\mathrm{N}$ stock by a rate 3.4 times that of agroforestry (Fig. 3b). The rates of annual decline in the SOC and $\mathrm{N}$ stocks after conversion from agroforestry to khat were estimated at $3.05 \mathrm{Mg} \mathrm{ha}^{-1}$ and $0.31 \mathrm{Mg} \mathrm{ha}^{-1}$, respectively. 


\section{The ratio of soil organic carbon stock to nitrogen stock}

The ratio of SOC stock to $\mathrm{N}$ stock $(\mathrm{C} / \mathrm{N})$ in both native forest and agroforestry was clearly smaller than that in khat monocropping ( $p=0.028$ and $p=0.018$, respectively) (Fig. 4). Pearson coefficients for the correlation between SOC and $\mathrm{N}(0-40 \mathrm{~cm})$ were greater for khat monocropping $(r=0.98$, $n=27)$ and agroforestry $(r=0.97, n=27)$ than for native forest $(r=0.88, n=27)(p<0.01)$.

\section{Carbon and nitrogen contents in leaf litter and fine roots}

The $\mathrm{N}$ content of leaf litter under agroforestry was higher than under forest and khat monocropping, whereas the similar difference in $\mathrm{C}$ was not statistically significant (Fig. 5a, c) and the differences between forest and khat monocropping

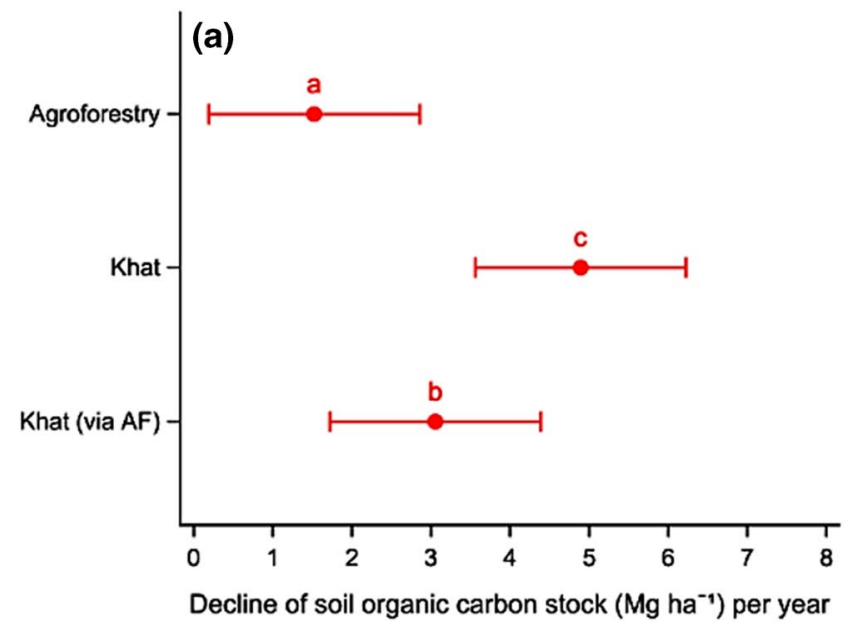

Fig. 3 Annual decline in soil carbon and nitrogen stocks. Mean estimates of the rates of loss of the soil organic carbon (a) and nitrogen (b) stocks by the fixed mass method as estimated by dividing the stocks by the duration. The lines show the lower and upper limits of

were small. Regarding fine roots, the median estimates of the $\mathrm{C}$ and $\mathrm{N}$ contents differed among the land uses $(p=0.002)$ and tended to be greater in the $0-20 \mathrm{~cm}$ soil layer than in the $20-40 \mathrm{~cm}(p=0.101)$ soil layer, whereas no statistically significant interaction between land use and depth $(p=0.804)$ was observed (Table S2). The $\mathrm{C}$ and $\mathrm{N}$ contents of fine roots in forest were nearly double those inputs in khat monocropping $(p=0.026)$ and nearly three times those in agroforestry $(p<0.001$ ) (Fig. 5b, d). The $\mathrm{C}$ and $\mathrm{N}$ contents of fine roots in khat were not statistically significantly greater than those in agroforestry $(p=0.171)$.

For the $\mathrm{N}$ contents of leaf litter, the median estimate differed among the land uses $(p<0.001)$ whereas for $\mathrm{C}$ there was a tendency only, being greater in agroforestry than in khat ( $p=0.103$ for $\mathrm{C}, p<0.001$ for $\mathrm{N}$, whereas there was a difference to forest for $\mathrm{N}$ only ( $p=0.201$ for $\mathrm{C}, p<0.001$ for $\mathrm{N}$ ) (Fig. 5b, d). The $\mathrm{C}$ and $\mathrm{N}$ in leaf litter in khat and

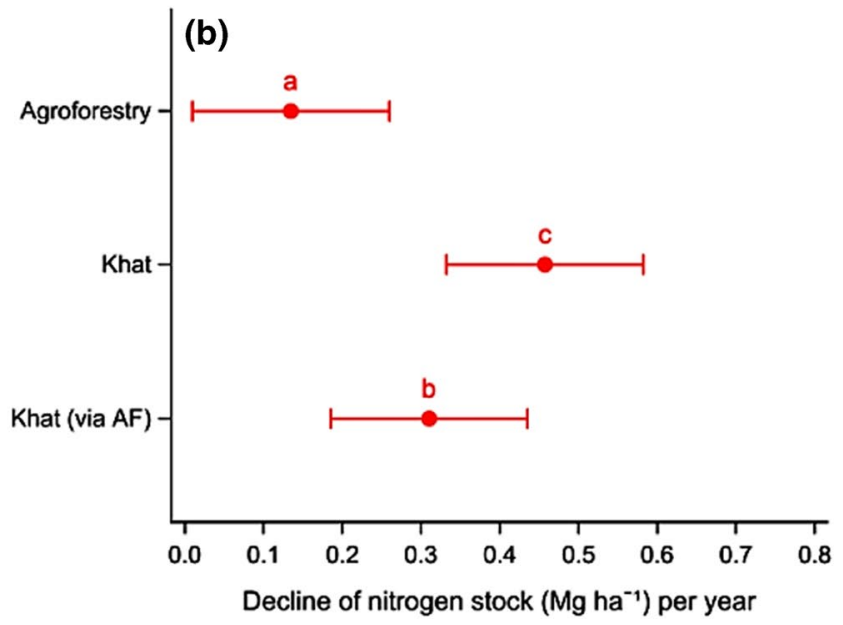

the $95 \%$ confidence intervals for the means, and different letters on the lines indicate statistically significant differences $(p<0.05)$. The sample size was 81

Fig. 4 Ratio of soil carbon and nitrogen. Mean estimates of $\mathrm{C} / \mathrm{N}$, i.e., the ratio of soil organic carbon and nitrogen stocks $\left(\mathrm{mg} \mathrm{ha}^{-1}\right)$ for land uses at the sampling depth of $0-40 \mathrm{~cm}$, by the fixed mass method. The lines show the lower and upper limits of the $95 \%$ confidence interval of the means, and different letters on the lines indicate statistically significant differences $(p<0.05)$. The sample size was 81

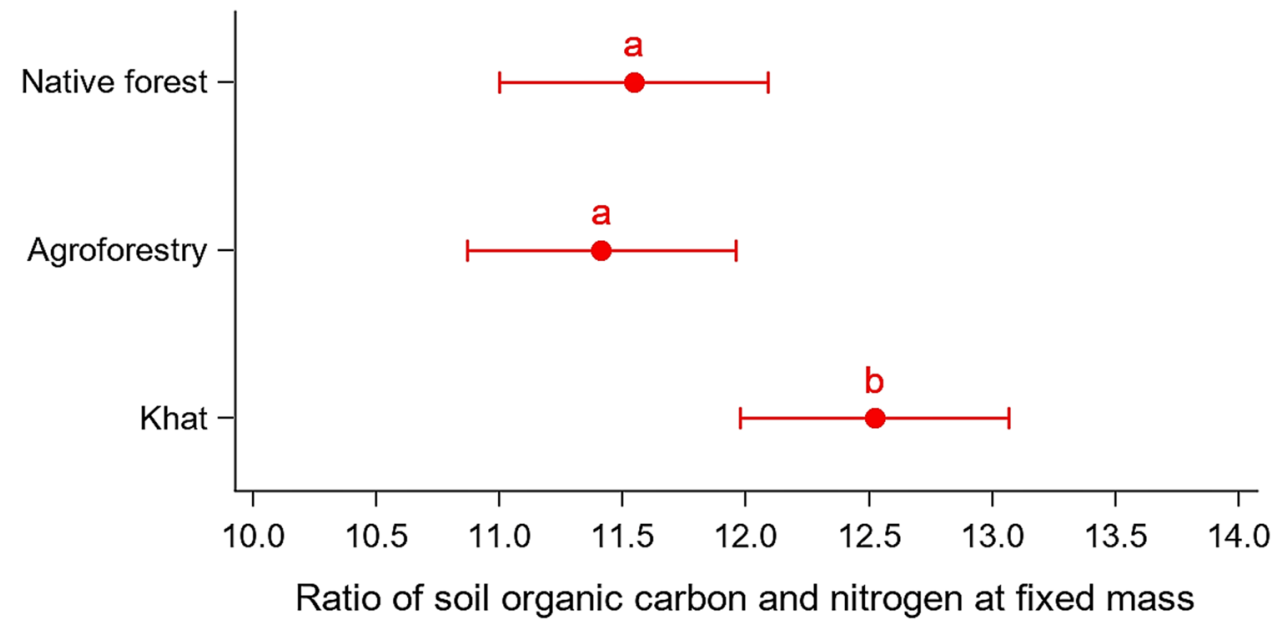

Ratio of soil organic carbon and nitrogen at fixed mass 

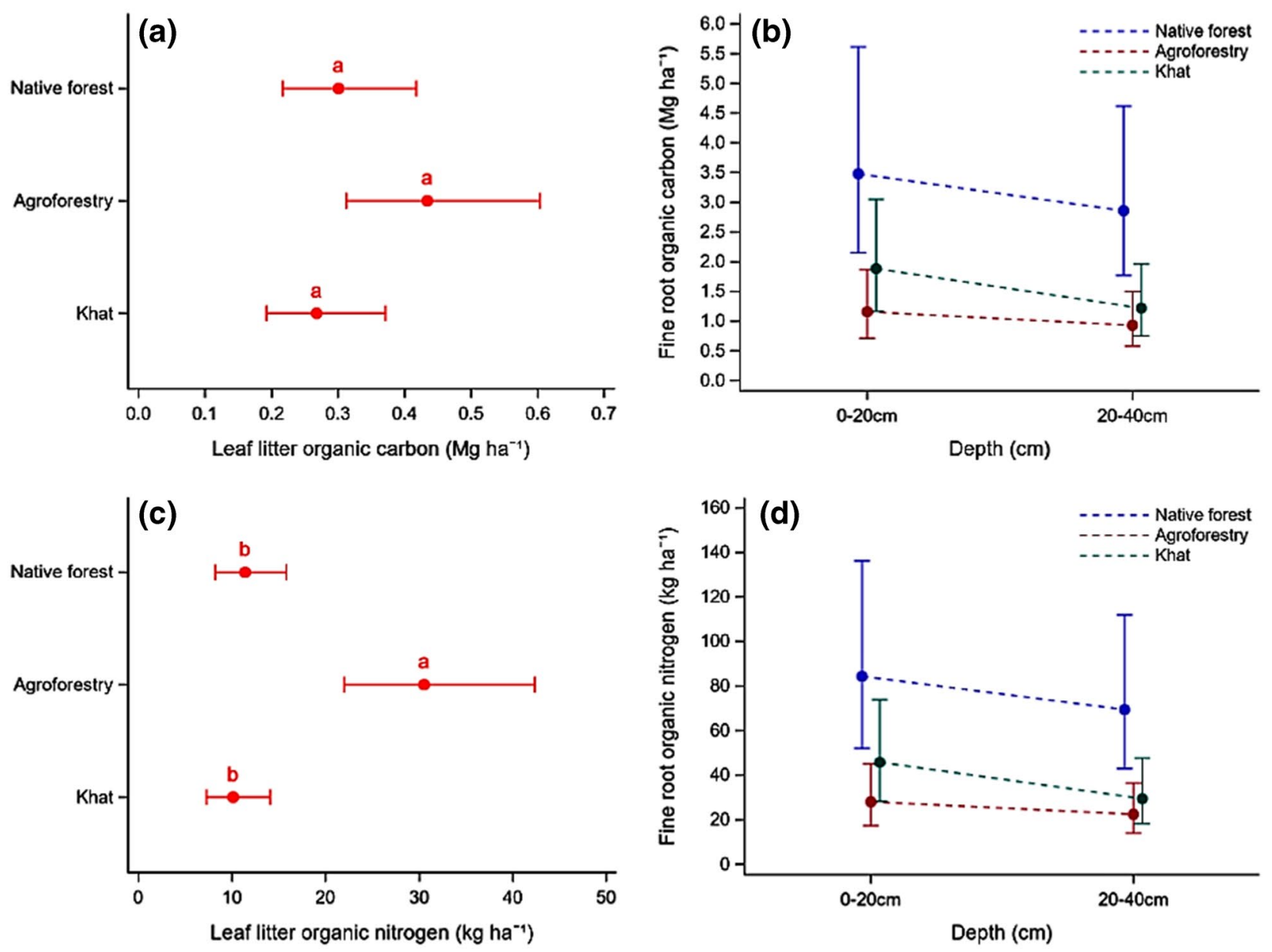

Fig. 5 Leaf litter and fine root carbon and nitrogen contents depending on the land use and soil depth. Median estimates of carbon contents in leaf litter (a) and fine roots (b) according to the soil depth and nitrogen contents in leaf litter (c) and fine roots (d). The lines show

the lower and upper limits of the $95 \%$ confidence intervals for the medians, and different letters on the lines indicate statistically significant differences $(p<0.05)$. The sample sizes were $162(\mathbf{a}, \mathbf{c})$ and 81 $(\mathbf{b}, \mathbf{d})$

forest did not differ ecologically nor were they statistically significantly different from each other $(p=0.603$ for both). The median estimates for the $\mathrm{C}$ contents in leaf litter were $301 \mathrm{~kg} \mathrm{ha}^{-1}$ in forest, $434 \mathrm{~kg} \mathrm{ha}^{-1}$ in agroforestry and $267 \mathrm{~kg} \mathrm{ha}^{-1}$ in khat. The $\mathrm{N}$ content of leaf litter was $31 \mathrm{~kg} \mathrm{ha}^{-1}$ in agroforestry and 10 and $11 \mathrm{~kg} \mathrm{ha}^{-1}$ for khat and forest.

\section{Discussion}

Our findings indicate that the SOC and $\mathrm{N}$ losses due to the conversion of native forests to perennial monocropping were substantially greater than due to conversion to agroforestry, and the annual rates of loss due to the conversion to khat monocropping were 3.0 and 3.4 times higher, respectively, than those due to the conversion to multistrata agroforestry. The $\mathrm{C}$ and $\mathrm{N}$ contents in leaf litter were greater

in agroforestry than in khat, but the contents in fine roots tended to be smallest in agroforestry.

\section{Khat cultivation leads to a greater collapse of soil organic carbon and nitrogen stocks than agroforestry}

Our hypothesis was confirmed by the multiple annual losses of SOC and N stocks from the conversion of native forest to perennial monocropping of khat relative to the conversion to multistrata agroforestry-based cash cropping. Regarding such a comparison between the forest conversion to multistrata-agroforestry-based cash cropping and to perennial monocropping of cash crops, there are no previous empirical findings to the best of our knowledge.

The $32 \%$ decline in SOC at 32-54 years of age in multistrata agroforestry that replaced native forest in our study does not support the findings of Kassa et al. (2017). They 
reported a nonsignificant decline after 15-25 years of the conversion moist Afromontane forest to multistrata agroforestry in southwestern Ethiopia. Here, the greater duration and sampling in replicated groups of matched adjacent plots of the compared land uses minimized the uncontrolled variation and might have affected the difference in this finding relative to Kassa et al. (2017). In addition, differences in the history of forest, land management after the conversion, climate etc. could contribute to the difference in results between the studies. The conversion of lowland rainforest to perennial cash crop plantations such as oil palm, rubber, and cacao reduced $\mathrm{C}$ residence time to one third or tenth (Kotowska et al. 2015) and SOC stocks by up to half (van Straaten et al. 2015) in Indonesia, Peru, and Cameroon and by $70 \%$ (Guillaume et al. 2015) after 15 years of conversion in Indonesia, relative to the $44 \%$ stock reduction in our study for the conversion to khat. The slight difference may be due to the higher initial SOC stocks in the lowland rainforest than in the Afromontane forest and the conversion through forest burning, while in our study, khat monocropping was established through clear cutting.

The superiority of the SOC and N stocks in the forest relative to multistrata agroforestry and khat was associated with the many times greater total litter (leaves plus fine roots) contents of $\mathrm{C}$ and $\mathrm{N}$ in forest and the lack of cultivation. Cultivation is a major cause of depletion of soil organic matter when a forest is converted to a managed ecosystem (Six et al. 2000). Mechanical cultivation of agroforestry and khat may have also contributed to the insignificant difference in the bulk density relative to native forest, in which the biological mechanisms forming soil structure may have compensated the mechanical effect on soil bulk density in the two former land uses. Also, the role of slightly higher clay content observed in native forest soil than in the adjacent plots of other land uses, probably due to the lower occurrence of erosion in native forest than in managed systems (Guillaume et al. 2015), cannot be excluded from favoring $\mathrm{C}$ sequestration and soil structure. The greater SOC and N stocks in agroforestry than those in khat were associated with the roughly twice as high leaf litter pool in agroforestry due to trees and a lack of harvest as well as with an $\mathrm{N}$ supply provided by legume trees, whereas khat monocropping lacks trees and khat leaves are periodically harvested with only small amounts of leaves remaining on the field. In similar enset-based southern Ethiopian agroforestry, trees contributed 87 to $95 \%$ to the modeled $\mathrm{C}$ and $\mathrm{N}$ inputs (Negash and Kanninen 2015). Also, the characteristics of the plant species may affect SOC and $\mathrm{N}$ stocks.

The clearly greater impact of forest conversion to agroforestry and especially to khat on the SOC and N stocks in the surface soil than in the subsoil, as observed here, reflects the differences in the turnover time of organic matter and $\mathrm{C}$ use efficiency in deeper soil layers, as observed by Spohn et al.
(2016). The surface soil is also more affected by cultivation in agroforestry and khat. In forests, they observed no change in $\mathrm{C}$ use efficiency between depths but an increase in the turnover time of organic matter along with depth, whereas in managed ecosystems, a greater proportion of $\mathrm{C}$ uptake was allocated to respiration in deeper layers.

\section{The implications of the findings}

The notable quantities of SOC stocks lost due to the ongoing conversion of native forests and of traditional agroforestry systems to cash monocropping, as shown by the current study, are of major importance. This empirical assessment emphasizes the potential to maintain major parts of the forest soil $\mathrm{C}$ and $\mathrm{N}$ stocks in multistrata agroforestry relative to cash monocropping. Advancing the understanding and practices requires that research on the potential of agroforestry provides details beyond the current tendency to consider agroforestry as one system (Ramesh et al. 2015; Hombegowda et al. 2016).

Stable SOC stocks accumulate over hundreds and thousands of years but can be lost rapidly (Liang and Balser 2012). The notable suppression of the loss of forest soil stocks following the conversion of forest to the traditional agroforestry systems dominant in southern Ethiopia relative to perennial monocropping is of major practical significance. The rapid ongoing conversion of native forest and traditional agroforestry to monocropping may be possible to slow through economic incentives (Kahiluoto et al. 2014; Walden et al., 2020) to conserve the existing, even irreversible, C stocks (Pedroni et al. 2010; Goldstein et al. 2020) while also providing income options for example from cash crops, and securing food. Consequently, access to the $\mathrm{C}$ market by smallholders managing agroforestry systems deserves attention in climate negotiations and by the private sector acting on voluntary $\mathrm{C}$ markets. Reduction of transaction costs of $\mathrm{C}$ trading by smallholders as well as upfront payments may also need to be introduced to strengthen the incentive.

Simultaneously, management of khat monocropping can be somewhat improved through implementation of mulching and minimum tillage as well as soil and water conservation to better maintain C and N (Lal 2004). However, khat monocropping may not guarantee stable income owing to sensitivity to diseases and price volatility. Consequently, integration of khat in agroforestry systems is one strategy to counteract impact of climate change and soil degradation while providing food, income, and multiple ecosystem services, also supported by the national adaptation action plan of Ethiopia (Ethiopia, Ministry of Water Resources and Meteorological Agency. 2007).

\section{Generalizability of the findings}

The land-use types studied represent a broad range of management systems in terms of the deterioration of SOC and 
$\mathrm{N}$ stocks. Khat is increasing in importance in Ethiopia; 30 to $60 \%$ of coffee-growing areas in Ethiopia are anticipated to become unsuitable for coffee by the end of this century because of climate change (Moat et al. 2017) even if adaptation efforts through cultivars, irrigation, and further integration agroforestry may improve the prospects. This, in turn, will likely provide further incentives for the expansion of khat, a crop adapted to broader climatic conditions than coffee (Lemessa 2001; Moat et al. 2017). The impact of khat monocropping in this study, even if crop- and managementspecific, is indicative of the effects of perennial cash crop monocropping replacing forests across the tropics.

The magnitude of SOC and N stock changes by forest conversion depends on site properties such as altitude and edaphic and climatic factors (Bruun et al. 2015; Lal et al. 2015) but is also critically dependent on new land use and management (Hughes et al. 2002). For example, the extensive root system of grassland may provide enough $\mathrm{C}$ to compensate for the mineralization of native forest $\mathrm{C}$ (Yimer et al. 2007). Grassland is not, however, an alternative to cash crops in terms of providing food and income to smallholders. Multistrata agroforestry might include both trees and patches of grassland while providing the opportunity to grow cash crops, such as coffee and khat in Ethiopia.

The degree of change in the SOC and N stocks following forest conversion depends on the duration of post-conversion management practices and thus on the current distance from the new steady state of the post-conversion management (Birch-Thomsen et al. 2007; Fujisaki et al. 2015). The duration of the agroforestry management of the sampled plots in our study varied from 32 to 54 years, whereas the duration of khat monocropping ranged from 15 to 27 years. This difference in duration, even if accounted for by assessing the annual rate of $\mathrm{C}$ stock decline, indicates a possible difference in the distance from the steady state between agroforestry and khat monocropping. Therefore, the total difference in SOC and N stock decline between these systems in the current study represents a conservative estimate. Because the measurements of leaf and root litters represent a one-time measurement (even if at a representative time), they indicate relative values of the land uses and are smaller than the modeled total litter accumulation values (Negash and Kanninen 2015) or the values measured for annually accumulated litter (Negash and Starr 2013).

\section{Conclusions}

The study showed the importance of promoting agroforestry when forests are converted to agricultural land for production of cash crops. The decline in soil SOC and N stocks under the expansion of khat monocropping, which is many times more rapid than that in agroforestry-based cash cropping, warrants strong measures. Economic incentives such as $\mathrm{C}$ payments may mitigate $\mathrm{SOC}$ stock losses if the incentives are also targeted to prevent the loss of the current stocks and not only to add stocks, and if the payments are accessible to smallholders. However, it is important to reduce the observed SOC and N stock declines in agroforestry as well. Agroforestry represents an extremely varied system where the properties determine the potential. Further research is therefore required to understand the dynamics that underpin differences in the SOC and N stocks of various agroforestry systems.

Supplementary Information The online version contains supplementary material available at https://doi.org/10.1007/s10113-022-01905-3.

Acknowledgements Special thanks are extended to the farmers of Arosa and Abo, to Zebene Asfaw, Woyinshet Afework, and natural resource experts working in agriculture offices of the studied districts, and to Hanna Mäkinen for contributions during the early stages of the work. We thank the staff at the soil laboratory of Natural Resources Institute Finland for the soil analyses.

Funding This work was supported by the Academy of Finland (SOILMAN project, Decision No. 270106/294135).

Open Access This article is licensed under a Creative Commons Attribution 4.0 International License, which permits use, sharing, adaptation, distribution and reproduction in any medium or format, as long as you give appropriate credit to the original author(s) and the source, provide a link to the Creative Commons licence, and indicate if changes were made. The images or other third party material in this article are included in the article's Creative Commons licence, unless indicated otherwise in a credit line to the material. If material is not included in the article's Creative Commons licence and your intended use is not permitted by statutory regulation or exceeds the permitted use, you will need to obtain permission directly from the copyright holder. To view a copy of this licence, visit http://creativecommons.org/licenses/by/4.0/.

\section{References}

Abebe T (2013) Determinants of crop diversity and composition in Enset-coffee agroforestry home gardens of southern Ethiopia. J Agr Rural Dev Trop. 114, 29-38. De:hebis: 34-2013030542580.

Aerts R (1997) Climate, leaf litter chemistry and leaf litter decomposition in terrestrial ecosystems: a triangular relationship. Oikos 79:439-449. https://doi.org/10.2307/3546886

Assefa D, Rewald B, Sandén H, Godbold DL (2017) Fine root dynamics in Afromontane forest and adjacent land uses in the northwest Ethiopian Highlands. Forests 8:249. https://doi.org/10.3390/f8070 249

Balaguer-Puig M, Marqués-Mateu Á, Lerma JL, Ibáñez-Asensio S (2018) Quantifying small-magnitude soil erosion: geomorphic change detection at plot scale. Land Degrad Dev 29:825-834. https://doi.org/10.1002/ldr.2826

Birch-Thomsen T, Elberling B, Fog B, Magid J (2007) Temporal and spatial trends in soil organic carbon stocks following maize cultivation in semi-arid Tanzania, East Africa. Nutr Cycling Agroecosyst 79:291-302. https://doi.org/10.1007/s10705-007-9116-4 
Bouyoucos GJ (1962) Hydrometer method improved for making particle size analysis of soils. Agron J 54:464-465. https://doi.org/10. 2134/agronj1962.00021962005400050028x

Bruun TB, Elberling B, De Neergaard A, Magid J (2015) Organic carbon dynamics in different soil types after conversion of forest to agriculture. Land Degrad Dev 26:272-283. https://doi.org/10. 1002/ldr.2205

Dawoe EK, Isaac ME, Quashie-Sam J (2010) Litterfall and litter nutrient dynamics under cocoa ecosystems in lowland humid Ghana. Plant Soil 330:55-64. https://doi.org/10.1007/s11104-009-0173-0

de Blécourt M, Brumme R, Xu J, Corre MD, Veldkamp E (2013) Soil carbon stocks decrease following conversion of secondary forests to rubber (Hevea brasiliensis) plantations. PLoS ONE 8:e69357. https://doi.org/10.1371/journal.pone.0069357

Dessie G, Kinlund P (2008) Khat expansion and forest decline in Wondo Genet, Ethiopia. Ethiopia. Geografiska Annaler: Series B, Human Geography 90:187-203. https://doi.org/10.1111/j.14680467.2008.00286.x.

Dessie, G (2013) Is Khat a Social Ill? Ethical argument about a stimulant among the learned Ethiopians, ASc Working Paper. African Study Center, Leiden, The Netherlands.

Dube DK, Hiranmai YR, Dube SK (2014) Why a shift from coffee to chat? A study of the Kersaworeda in Jimma zone of South Western Ethiopia. Res Humanit Soc Sci 4:176-182

Ellert BH, Bettany JR (1995) Calculation of organic matter and nutrients stored in soils under contrasting management regimes. Can J Soil Sci 75:529-538. https://doi.org/10.4141/cjss95-075

Ellert BH, Rock L (2007) Stable isotopes in soil and environmental research. In: Gregorich EG, Carter MR (eds) Soil sampling and methods of analysis, 2nd edn. CRC Press, Boca Raton, Fl, USA, pp 693-711

Emich M (2003) The human ecology of Mayan cacao farming In Belize. Hum Ecol 31:111-131. https://doi.org/10.1023/A:10228 86208328

Ethiopia, Ministry of Water Resources and Meteorological Agency (2007) Tadege, Abebe (ed). Climate Change NAPA of Ethiopia. http://unfccc.int/resource/docs/napa/eth01 (accessed 07/09/2019).

FAO (2001) Lecture notes on the major soils of the world. Driessen P, Deckers J, Spaargaren O, Nachtergaele F (eds) World Soil Resources Report No. 94. Rome

Feyisa TH, Aune JB (2003) Khat expansion in the Ethiopian Highlands: effects on the farming system in Habro District. Mt Res Dev 23:185-189. https://doi.org/10.2307/3674490

Fujisaki K, Perrin AS, Desjardins T, Bernoux M, Balbino LC, et al. (2015) From forest to cropland and pasture systems: a critical review of soil organic carbon stocks changes in Amazonia. Glob Change Biol 21:2773-2786. https://doi.org/10.1111/gcb.12906

Gbur E, Stroup WW, McCarter KS, Durham S, Young LJ, et al. (2012) Analysis of generalized linear mixed models in the agricultural and natural resources sciences. American Society of Agronomy, Madison

Getnet D (2016) Comparative analysis of biomass and soil carbon stocks in multistrata agroforestry systems and khat (catha edulis) farming: the case of Raya Azebo, Northern Ethiopia. M.Sc thesis. Hawassa University, Ethiopia

Goldstein A, Turner WR, Spawn SA, Anderson-Teixeira KJ, CookPatton S, et al. (2020) Protecting irrecoverable carbon in Earth's ecosystems. Nat Clim Chang 10:287-295. https://doi.org/10.1038/ s41558-020-0738-8

Gordon WS, Jackson R (2000) Nutrient concentrations in fine roots. Ecology 81:275-280. https://doi.org/10.2307/177151

Guillaume T, Damris M, Kuzyakov Y (2015) Losses of soil carbon by converting tropical forest to plantations: erosion and decomposition estimated by $\delta 13 \mathrm{C}$. Glob Change Biol 21:3548-3560. https:// doi.org/10.1111/gcb.12907
Hombegowda HC, van Straaten O, Köhler M, Hölscher D (2016) On the rebound: soil organic carbon stocks can bounce back to near forest levels when agroforests replace agriculture in southern India. Soil 2:13-23. https://doi.org/10.5194/soild-2-871-2015

Hughes RF, Kauffman JB, Cummings DL (2002) Dynamics of aboveground and soil carbon and nitrogen stocks and cycling of available nitrogen along a land-use gradient in Rondônia, Brazil. Ecosystems 5:244-259. https://doi.org/10.1007/s10021-001-0069-1

IPCC (2006) guidelines for national greenhouse gas inventories, prepared by the National Greenhouse Gas Inventories Programme, Eggleston HS, Buendia L, Miwa K, Ngara T and Tanabe K (eds). Published: IGES, Japan.

Kahiluoto H, Smith P, Moran D, Olesen JE (2014) Enabling food security by verifying agricultural carbon. Nat Clim Chang 4:3093011. https://doi.org/10.1038/nclimate2209

Kassa H, Dondeyne S, Poesen J, Frank A, Nyssen J (2017) Impact of deforestation on soil fertility, soil carbon and nitrogen stocks: the case of the Gacheb catchment in the White Nile Basin. Ethiopia Agric Ecosyst Environ 247:273-282. https://doi.org/10.1016/j. agee.2017.06.034

Keenan RJ, Reams GA, Achard F, de Freitas JV, Grainger A, et al. (2015) Dynamics of global forest area: results from the FAO Global Forest Resources Assessment 2015. For Ecol Manag 352:9-20. https://doi.org/10.1016/j.foreco.2015.06.014

Kenward MG, Roger JH (2009) An improved approximation to the precision of fixed effects from restricted maximum likelihood. Comput Stat Data Anal 53:2583-2595. https://doi.org/10.1016/j. csda.2008.12.013

Kim D-G, Terefe B, Girma S, Kedir H, Morkie N, et al. (2016) Conversion of home garden agroforestry to crop fields reduced soil carbon and nitrogen stocks in southern Ethiopia. Agrofor Syst 90:251-264. https://doi.org/10.1007/s10457-10015-19851-10455

Köhler L, Hölscher D, Leuschner C (2008) High litterfall in oldgrowth and secondary upper montane forest of Costa Rica. Plant Ecol 199:163-173. https://doi.org/10.1007/s11258-008-9421-2

Kotowska MM, Leuschner CS, Triadiati T, Meriem S, Hertel D (2015) Quantifying above- and belowground biomass carbon loss with forest conversion in tropical lowlands of Sumatra (Indonesia). Glob Change Biol 21:3620-3634. https://doi.org/10.1111/gcb. 12979

Lal R (2004) Soil carbon sequestration to mitigate climate change. Geoderma 123:1-22. https://doi.org/10.1016/j.geoderma.2004. 01.032

Lal R, Negassa W, Lorenz K (2015) Carbon sequestration in soil. Curr Opin Env Sust 15:79-86. https://doi.org/10.1016/j.cosust.2015. 09.002

Lehmann J (2006) A handful of carbon. Nature 447:143-144. https:// doi.org/10.1038/447143a

Lemessa D (2001) Khat (Catha edulis): botany, distribution, cultivation, usage and economics in Ethiopia (Agriculturalist), UNemergencies unit for Ethiopia, Addis Ababa, June 2001.

Liang C, Balser TC (2012) Warming and nitrogen deposition lessen microbial residue contribution to soil carbon pool. Nat Commun 3:1222. https://doi.org/10.1038/ncomms2224

Liang C, Schimel JP, Jastrow JD (2017) The importance of anabolism in microbial control over soil carbon storage. Nat Microbiol 2(8):17105. https://doi.org/10.1038/nmicrobiol.2017.105

Liu C, Westman CJ, Berg J, Kutsch W, Wang GZ, et al. (2004) Variation in litter fall-climate relationships between coniferous and broadleaved forests in Eurasia. Glob Ecol 13:105-114. https:// doi.org/10.1111/j.1466-882X.2004.00072.x

Málaga N, Hergoualćh K, Kapp G, Martius C (2020) Variation in vegetation and ecosystem carbon stock due to the conversion of disturbed forest to oil palm plantation in Peruvian Amazonia. Ecosystems https://doi.org/10.1007/s10021-020-00521-8 
MEFCC (2016) Ethiopia's forest reference level submission to the UNFCCC. Ministry of Environment, Forest and Climate Change. Addis Ababa, Ethiopia.

MEFCC (2018) National REDD+ Strategy (2018-2030), Ministry of Environment, Forest and Climate Change, Addis Ababa, Ethiopia.

Mekuria W (2018) Public discourse on khat (Catha edulis) production in Ethiopia: review. J Agric Ext Rural Dev 10(10):192-200. https://doi.org/10.5897/jaerd2018.0984

Mellisse BT, van de Ven GWJ, Giller KE, Descheemaeker K (2018) Home garden system dynamics in Southern Ethiopia. Agrofor Syst 92:1579-1595. https://doi.org/10.1007/s10457-017-0106-5

Ministry of environment, forest and climate change (MEFCC) (2018) national potential and priority maps for tree-based landscape restoration in Ethiopia (version 0.0): technical report. Addis Ababa: Ministry of Environment, Forest and Climate Change.

Moat J, Jenny W, Baena S, Wilkinson T, Gole TW, et al. (2017) Resilience potential of the Ethiopian coffee sector under climate change. Nat Plants 3(17081):1-14. https://doi.org/10.1038/nplan ts. 2017.81

Muñoz F, Beer J (2001) Fine root dynamics of shaded cacao plantations in Costa Rica. Agrofor Syst 51:119-130. https://doi.org/10. 1023/A:1010651203815

Murovhi NR, Materechera SA, Mulugeta SD (2012) Seasonal changes in litter fall and its quality from three sub-tropical fruit tree species at Nelspruit South Africa. Agrofor Syst 86:61-71. https://doi. org/10.1007/s10457-012-9508-6

Negash M, Kanninen M (2015) Modeling biomass and soil carbon pools change of indigenous agroforestry system using CO2FIX approach. Agric Ecosyst Environ 203:147-155. https://doi.org/ 10.1016/j.agee.2015.02.004

Negash M, Starr M (2013) Litterfall production and associated carbon and nitrogen fluxes of seven woody species grown in indigenous agroforestry systems in the Rift Valley escarpment of Ethiopia. Nutr Cycling Agroecosyst 97:29-41. https://doi.org/10.1007/ s10705-013-9590-9

Negash M, Starr M (2015) Biomass and soil carbon stocks of indigenous agroforestry systems on the south-eastern Rift Valley escarpment, Ethiopia. Plant Soil 393:95-107. https://doi.org/10.1007/ s11104-015-2469-6

Nygren P, Leblan HA, Lu M, Luciano CAG (2013) Distribution of coarse and fine roots of Theobroma cacao and shade tree Inga edulis in a cocoa plantation. Ann for Sci 70:229-239. https://doi. org/10.1007/s13595-012-0250-z

O'Rourke SM, Angers DA, Holden NM, McBratney AB (2015) Soil organic carbon across scales. Global Change Biology 21:35613574. https://doi.org/10.1111/gcb.12959

Pan Y, Birdsey RA, Fang J, Houghton R, Kauppi PE, et al. (2011) A large and persistent carbon sink in the world's forests. Science 333:988-993. https://doi.org/10.1126/science.1201609

Pedroni L, Dutschke M, Streck C, Porrúa ME (2010) Creating incentives for avoiding further deforestation: the nested approach. In: Dutschke M, Forestry, Risk and Climate Policy, 2009. PhD dissertation, University of Groningen. CUVILLIER VERLAG, Göttingen

Post WM, Eanuwel WR, Zinke PJ, Stangenberger AG (1982) Soil carbon pools and world life zones. Nature 298:156-159

Powers JS (2004) Changes in soil carbon and nitrogen after contrasting land-use transitions in northeastern Costa Rica. Ecosystems 7:134-146. https://doi.org/10.1007/s10021-003-0123-2

Raizada A, Jayaprakash J, Rathore AC, Tomar JMS (2013) Distribution of fine root biomass of fruit and forest tree species raised on old river bed lands in the north west Himalaya Tropical Ecology 54(2):251-261
Ramesh T, Manjaiah K, Mohopatra KP, Rajasekar K, Ngachan SV (2015) Assessment of soil organic carbon stocks and fractions under different agroforestry systems in subtropical hill agroecosystems of north-east India. Agrofor Syst 89:677-690

Rimhanen K, Ketoja E, Yli-Halla M, Kahiluoto H (2016) Ethiopian agriculture has greater potential for carbon sequestration than previously estimated. Glob Change Biol 22:3739-3749. https:// doi.org/10.1111/gcb.13288

Six J, Elliott ET, Paustian K (2000) Soil macroaggregate turnover and microaggregate formation: a mechanism for $\mathrm{C}$ sequestration under no-tillage agriculture. Soil Biol 32:2099-2103. https://doi.org/10. 1016/S0038-0717(00)00179-6

Sloan S, Sayer JA (2015) Forest Resources Assessment of 2015 shows positive global trends but forest loss and degradation persist in poor tropical countries. For Ecol Manag 352:134-145. https:// doi.org/10.1016/j.foreco.2015.06.013

Smith P, House JI, Bustamante M, Sobockà J, Harper R, et al. (2016) Global change pressures on soils from land use and management. Glob Change Biol 22:1008-1028. https://doi.org/10.1111/gcb. 13068

Solomon D, Fritzsche F, Lehmann J, Tekalign M, Zech W (2002) Soil organic matter dynamics in the sub-humid agroecosystems of the Ethiopian highlands: evidence from natural 13C abundance and particle-size fractionation. Soil Sci Soc Am J 66:969-978. https:// doi.org/10.2136/sssaj2002.0969

Spohn M, Klaus K, Wanek W, Richter A (2016) Microbial carbon use efficiency and biomass turnover times depending on soil depth - implications for carbon cycling. Soil Biol Biochem 96:74-81. https://doi.org/10.1016/j.soilbio.2016.01.016

Tolcha PT (2020) Khat marketing and its export performance in the Ethiopian economy. Strateg Bus Change Manag 7(2):58-69

van Straaten O, Corre MD, Wolf K, Tchienkoua M, Cuellar E, et al. (2015) Conversion of lowland tropical forests to tree cash crop plantations loses up to one-half of stored soil organic carbon. PNAS 112:9956-9960. https://doi.org/10.1073/pnas.1504628112

Wabel NT (2011) Psychopharmacological aspects of Catha edulis (khat) and consequences of long term use, a review. J Affect Disord $1: 187$

Walden P, Ollikainen M, Kahiluoto H (2020) Carbon revenue in the profitability of agroforestry relative to monocultures. Agrofor Syst 94:15-28. https://doi.org/10.1007/s10457-019-00355-x

Wendt JW, Hauser S (2013) An equivalent soil mass procedure for monitoring soil organic carbon in multiple soil layers. Eur J Soil Sci 64:58-65. https://doi.org/10.1111/ejss.12002

Westfall PH (1997) Multiple testing of general contrasts using logical constraints and correlations. J Am Stat Assoc 92:299-306. https:// doi.org/10.1080/01621459.1997.10473627

Woldu Z, Belew D, Benti T (2015) The coffee-khat interface in eastern Ethiopia: a controversial land use and livelihood change scenario. J Agr Sci Tech-Iran B 5, 149-169. https://doi.org/10.17265/21616264/2015.03.001

Yimer F, Ledin S, Abdelkadir A (2007) Changes in soil organic carbon and total nitrogen contents in three adjacent land use types in the Bale Mountains, south-eastern highlands of Ethiopia. For Ecol Manag 242:337-342. https://doi.org/10.1016/j.foreco.2007.01.087

Publisher's Note Springer Nature remains neutral with regard to jurisdictional claims in published maps and institutional affiliations. 